\title{
Media value of the Polish sports sponsorship market in the years 2015-2017
}

\author{
Authors' Contribution: \\ A Study Design \\ B Data Collection \\ C Statistical Analysis \\ D Data Interpretation \\ E Manuscript Preparation \\ F Literature Search \\ G Funds Collection
}

\author{
Gabriel Łasiński $^{\text {ACDEF }}$, Adam Pawlukiewicz ${ }^{\text {ABCDEF }}$ \\ Chair of Communication and Management in Sport, \\ University School of Physical Education in Wroclaw, Poland
}

\section{abstract}

Background: Recently, there has been a dynamic development of sports sponsorship, which is becoming an alternative to conventional advertising. One of the main methods of sponsorship evaluation is the media value assessment of the brand exposure involved in this form of promotion. The aim of this study was to determine the leading sports disciplines in the aspect of the media value they generate and to indicate the effectiveness of sports sponsorship according to conventional advertising activities.

Material and methods:

Results: The conducted research confirmed the dominance of football over the remaining disciplines in terms of popularity and attractiveness of the programming offer on television.

Conclusions:

Key words:

\section{article details}

Article statistics:

Full-text PDF:

Copyright

Indexation:

Received: November 2018; Accepted: January 2019; Published: June 2019 years also seem to be most valuable for marketing strategies. Obviously, this popularity will affect the result of the media value.

sports sponsorship, media value, advertising value equivalency, media monitoring, sports sponsorship effectiveness.

Word count: 4,309; Tables: 3; Figures: 7; References: 17

http://www.balticsportscience.com

(c) Gdansk University of Physical Education and Sport, Poland

Celdes, Clarivate Analytics Emerging Sources Citation Index (ESCI), CNKI Scholar (China National Knowledge Infrastructure), CNPIEC, De Gruyter - IBR (International Bibliography of Reviews of Scholarly Literature in the Humanities and Social Sciences), De Gruyter - IBZ (International Bibliography of Periodical Literature in the Humanities and Social Sciences), DOAJ, EBSCO - Central \& Eastern European Academic Source, EBSCO SPORTDiscus, EBSCO Discovery Service, Google Scholar, Index Copernicus, J-Gate, Naviga (Softweco, Primo Central (ExLibris), ProQuest - Family Health, ProQuest - Health \& Medical Complete, ProQuest - Illustrata: Health Sciences, ProQuest - Nursing \& Allied Health Source, Summon (Serials Solutions/ProQuest, TDOne (TDNet), Ulrich's Periodicals Directory/ulrichsweb, WorldCat (OCLC)

Funding: This research received no specific grant from any funding agency in the public, commercial, or not-for-profit sectors.

Conflict of interests Corresponding author:

Open Access License:
Authors have declared that no competing interest exists.

Corresponding author: prof. dr hab. Gabriel Łasiński, Chair of Communication and Managing in Sport, University School of Physical Education, Paderewski Av. 35, 51-612 Wroclaw, Poland; E-mail: gabriel.lasinski@awf.wroc.pl; phone no.: +48 71 3473306.

This is an open access article distributed under the terms of the Creative Commons Attribution-Non-commercial 4.0 International (http://creativecommons.org/licenses/by-nc/4.0/), which permits use, distribution, and reproduction in any medium, provided the original work is properly cited, the use is non-commercial and is otherwise in compliance with the license. 


\section{INTRODUCTION}

Sport is becoming an object of growing interest for the traditional and new media as well as for research and business communities. It provides the organizations operating on the media market with profitable content, as the quality sports broadcasts are accompanied by record television and Internet audiences, the most expensive sponsorship services or packages and the most expensive advertising unattainable for other markets. On the other hand, the media are a carrier of information, promotion and image building without which modern sports sponsorship and marketing are impossible. The media and business interest in sport influences its further popularization, promotion and financial support. In recent years, there have been more frequent talks about different aspects of the market mediatization of sports, i.e. increasing subordination of sports events to the requirements of TV listings and requirements of advertisers and sponsors [1]. The media interest in sports makes it a central social phenomenon in the minds of its recipients. Its presence in the media and the resulting affective relations make it increasingly appealing for the business area [2, 3]. Therefore, involvement of many companies representing various industries as well as private individuals in sports sponsorship becomes inevitable.

Sponsorship is the provision of resources in the form of money, people or equipment, by an organization directly related to an event or action in exchange for a direct link to such event or activity [4]. At present, modern sponsorship is used as an activity to increase the competitiveness of companies on the market. It is considered an alternative form of promotion to advertising which in view of ad-oversaturation of the daily life with its different forms is decreasing in effectiveness [5]. Additionally, sponsorship allows reaching target groups that are difficult to reach with the use of conventional advertising [6]. The advantage of sponsorship over advertising expressed in a stronger message interfering with the attitudes and behaviour of consumers has been confirmed in many scientific studies [7]. A British research company KeyNote in its market report for 2010 estimates that main sponsorship transactions in the UK grew from 353 million pounds to 486 million pounds in the last decade. Due to the confidentiality of sponsorship contracts, it is difficult to state the real value of the sports sponsorship market, so the numbers presented in this study may be extremely useful for the estimation of the market potential.

It is indicated that the principle of good sponsorship is the quid pro quo philosophy, "something for something" [8], in other words a business transaction with measurable benefits for both parties participating in the sponsorship process: the sponsee and the sponsor. The unusual oversaturation of the advertising market [9], consumers turning away from advertising and its broad presence in the everyday life make the marketing departments of the world's largest companies look for alternative methods to reach consumers, other than and, above all, more effective than advertising. Sponsorship presents a great alternative, as it is a permanent element of sports competitions. The advertising forms of sponsors are not as invasive as advertisements, and in specific cases they may vary or enrich the sporting event, e.g. by simultaneous presentation of accurate statistics (speed, time, distance) [6].

One of the main methods of sponsorship evaluation is the assessment of the media value of the exposure of brands involved in this form of promotion. This is reflected in the dynamic development of sports sponsorship, which is becoming an alternative to conventional advertising. 
Table 1. Value of Polish advertising market in 2017 divided into media types (PLN billion)

\begin{tabular}{cc} 
Medium & Advertising market value in 2017 \\
\hline Television & PLN 4.1 bn \\
Internet & PLN 2.8 bn \\
Radio & PLN 0.7 bn \\
Press (magazines + journals) & PLN 0.5 bn \\
\hline
\end{tabular}

Source: Own elaboration on the basis of report by Starcom 2017 [10].

This article aims to provide knowledge that will allow improving the understanding of empirical aspects and media research terminology, as there is a lack of publications in the Polish and world literature explaining many concepts and dependencies related to this subject [11]. Authors decided to answer the following key questions: which disciplines attract the media attention, the time and place of presentation of competitions, the intensity and place of presentation of sponsors during sports events and how it is translated into the so-called media value. A thesis was adopted that the popularity, spectacularity and the specific nature of sports disciplines are crucial for the effectiveness of sports sponsorship.

The aim: Determination of the leading sports disciplines in the aspect of the media value they generate and an indication of the effectiveness of sports sponsorship against conventional advertising activities.

Research questions:

1. Which disciplines and for what reasons receive the highest media value in particular groups of television broadcasters in each analysed year?

2. Which television broadcasters had the highest exposure value of sponsors in 2016 and 2017 ?

3. What is the reason for the attractiveness of sports sponsorship for its potential investors?

\section{MATERIAL AND METHODS}

The subject of the research was the media data concerning the companies sponsoring sports events broadcast on the Polish television channels. Mostly, empirical research carried out in 2015, 2016 and 2017 by Pentagon Research was used. To illustrate the real increase in the market value, in the results section, the annual summary of the media value was presented from the beginning of the permanent study, i.e. from 2001. The research methodology was developed by the Media Research Team also at Pentagon Research, where one of the authors of this article has been working since 2012 .

The study was based on a daily analysis of recordings of Polish TV channels (in particular during the years 2015-2017) for the occurrence of sports sponsors brands in them and covered the following channels:

$\begin{array}{lll}- \text { TVP1 } & \text { - Polsat Sport Extra } & \bullet \text { Eurosport1 } \\ \text { - TVP2 } & \text { - Super Polsat } & \bullet \text { Eurosport2 } \\ \text { - TVP Info } & \text { - Super Polsat } & \bullet \text { nSport+ } \\ \text { - TVP Polonia } & \bullet \text { TV4 } & \bullet \text { Canal+ } \\ \text { - TVP Sport } & \bullet \text { TVN } & \bullet \text { Canal+Sport } \\ \text { - Polsat } & \bullet \text { TVN Turbo } & \bullet \text { Canal+Sport2 } \\ \text { - Polsat Sport } & - \text { TVN24 } & \end{array}$


The sponsors' logotypes were measured with the Pentagon Sponsor Track software system which allows tracking and recognising the brands presented at sports events at TV stations (in this case in Poland) and then subjects them to valuation.

An hourly video recording of a selected TV station takes about 300-600 MB of server space and is recorded in the standard format of television broadcasting in Poland (the so-called SD quality). For some events, recordings are also recorded in the HD format (720p or higher resolution).

For the purposes of the study discussed in this article, those sports programs (including TV news) were monitored in which Polish events or events with the participation of Polish athletes were shown. The brands exhibited on Polish players' outfits, stadiums, halls, sports facilities or media activities in sports, such as press conferences, as well as Polish brands displayed on foreign players' outfits or other media carriers were listed. The results of the media study were presented in "Sponsor Panel", a dedicated web application designed by Pentagon Research. This application is an interactive method of data presentation and a useful tool to evaluate sponsoring activities in the media. Sponsor Panel is currently used by several major sports sponsors in Poland. Below a description of two selected, specific TV screenshots is presented, which is available from the user level in the discussed platform.

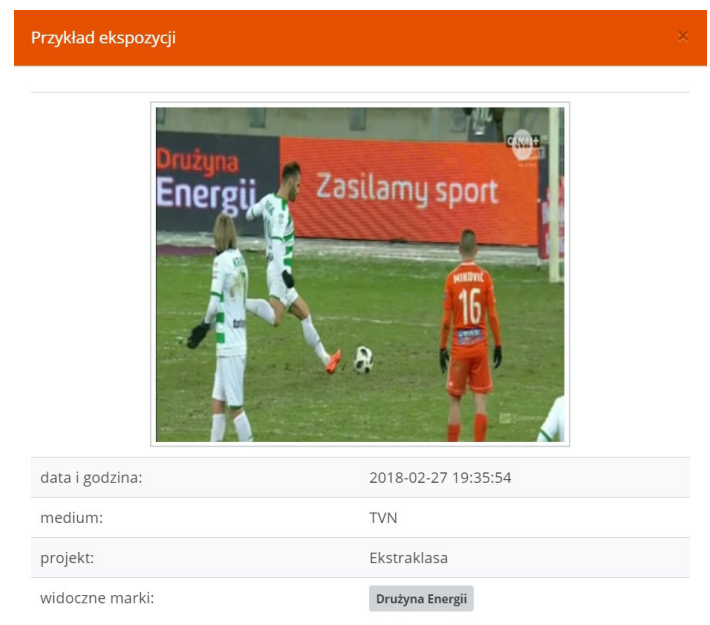

Fig.1. Screenshot from media research. An example of an exposition.

Source: Own elaboration based on internet application "Lechia Gdańsk Sponsor Panel" 2018.

The first screenshot above presents the "Drużyna Energii" brand during the sports news program on the TVN channel. The sports news on TVN usually offer much time to the Ekstraklasa football games. "Drużyna Energii" brand was presented on LED boards surrounding the football pitch during the match of Lechia Gdańsk, which is sponsored by Energa, and the "Drużyna Energii" brand is a marketing activity conducted in cooperation with the club.

The second screenshot below demonstrates that several sponsors may be displayed within a second, and in this particular case, there are four brands: Cekol, New Balance, Totolotek and OSHEE. All these brands sponsor Lechia Gdańsk, while OSHEE additionally is a sponsor of the entire LOTTO EXTRAKLASA league. 


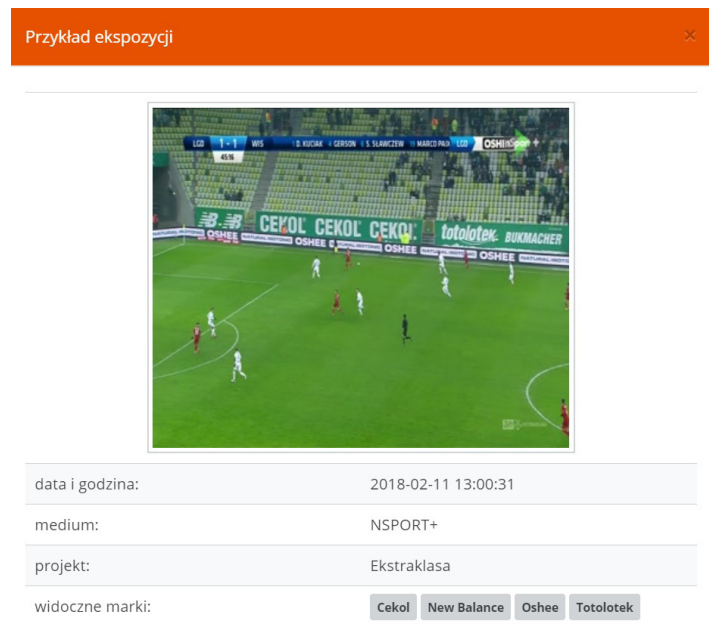

Fig.2. Screenshot from media research. An example of an exposition.

Source: Own elaboration based on internet application "Lechia Gdańsk Sponsor Panel" 2018.

\section{INTERPRETATION OF SELECTED FACTORS AND INDICATORS USED IN THE STUDY OF MEDIA VALUE ON TELEVISION}

CPT/CPM (Cost per thousand/Cost per mille, Latin mille - thousand) [12]

- the average cost of reaching up to 1000 people in a given target group is usually referred to the 30-second length of an advertising spot [13];

- it is used as a measure of the cost effectiveness of an advertising campaign or to compare the differences in prices of advertisements on various television stations.

AVE (Media value or equivalent of advertising value)

- is calculated based on the average cpt (cost per thousand) for the monitored stations and the average viewership of TV programs when brands were displayed;

- authors of the study (Pentagon Research) count the so-called effective exposures, i.e. well visible (clear), lasting at least 1 second and not fragmentary (minimum $80 \%$ visibility);

- the media value shows the estimated cost that would have to be incurred to obtain a similar GRP (gross rating point) with the use of conventional advertising;

- is a commonly used method to measure the alleged value of public relations resulting from involuntary advertising on TV via media which the broadcast concerns or in editorial texts (Jeffress-Fox, 2003).

\section{Number of contacts}

- is the sum of the products of the brand's exposure with the average number of viewers of the program being the subject of monitoring.

\section{Telemetry}

- the data which present the popularity of individual programs. They were received as part of a partnership with NIELSEN MEDIA RESEARCH which conducts a telemetry study in Poland.

- the data of the Central Statistical Office (GUS) and an analysis of the society structure conducted as part of the Establishment Survey are used for the construction of the panel and its modifications. It is conducted every year in two stages: spring and autumn by a research company (e.g. AC Nielsen in 2014).

- the study covers 8,000 households annually drawn from the GUS database of addresses, which are a specific representation for acquiring knowledge about 
the population of Poles watching television (a representative method in the research process, used similarly as in sociology) [14].

\section{GRP (Gross Rating Point)}

- a measure of intensity (power) of a campaign expressed as the sum of the ranges for individual emissions or ratio of campaign's reach and its frequency [15]. The term is used during the purchase process of the advertising spots on television [16].

\section{RESULTS}

In order to answer the research questions, the authors decided at the beginning of this section to present a graph summarizing the study of the media value of sponsoring for the entire sports market since 2001, i.e. from the moment when the sports market analysis started. The graph clearly shows that in the last 16 years there has been a significant increase in the value of the advertising equivalent of sponsors. The largest growth, expressed in the numerical value for each year, was recorded in 2016, which was a record year in the history of this type of research in Poland. The market stabilization at a high level of its value of over PLN 3.5 billion from 2013 and over PLN 4 billion in the last two years of research resulted in significant premises for the preparation of this publication and an explanation of the methodology of this study.

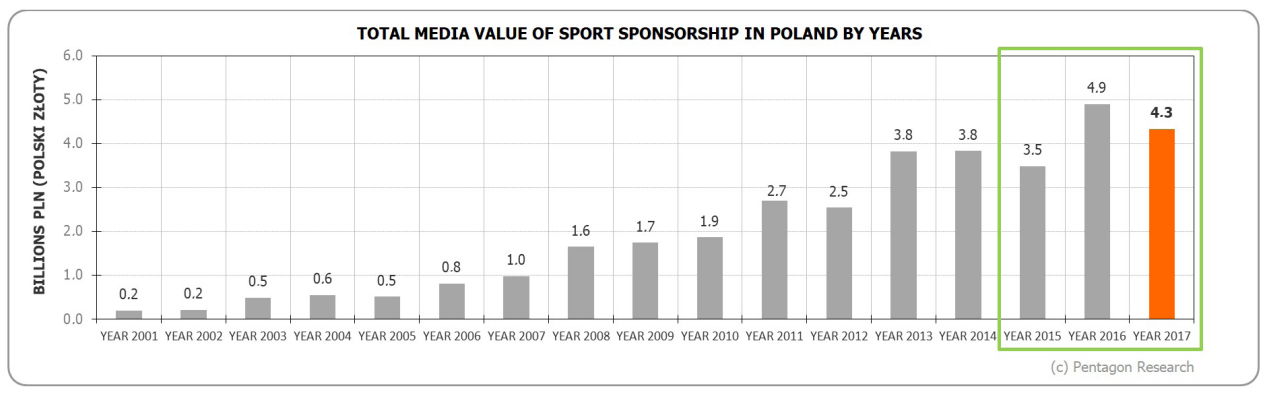

Fig. 3. Total media value of sport sponsorship in Poland by years (2001-2017)

Source: Own elaboration based on own data of Pentagon Research 2018.

In their analysis, the authors focused on the last three years of research, and the next paragraph lists the most important sports events that influenced and built the media value in the years 2015, 2016 and 2017.

The TV value of sports sponsorship in 2015 (official value, without considering the rebate policy of individual channels) amounted to PLN 3.49 billion, which is slightly less than in the two previous years.

This value mainly consisted of:

- qualification of the Polish national football team to UEFA EURO 2016,

- increase in the popularity of volleyball after winning the World Championship by the team of Stefan Antiga,

- the World Athletics Championships, gold medal of Piotr Małachowski,

- the excellent physical shape of Anita Włodarczyk throughout the year (world record $81.08 \mathrm{~m}$ ),

- Katarzyna Niewiadoma with the silver medal of the European Games,

- Tour de Pologne 2015,

- the bronze medal of the Polish national handball team at the World Championships in Qatar. 
The TV value of sports sponsorship in 2016 amounted to PLN 4.9 billion and it was the best result in the history of media research.

The above high value is the result of the following:

- reaching the quarterfinals of UEFA EURO 2016 by the Polish football team,

- 11 Polish medals at the Olympics in Rio de Janeiro,

- a good start of the 2016/2017 season by Polish ski jumpers,

- organization of the 2016 European Handball Championship in Poland,

- Tour de Pologne 2016,

- World League Final Tournament,

- Legia Warszawa participation in the UEFA Champions League 2016/2017.

The TV value of sports sponsorship in 2017 amounted to PLN 4.3 billion. It was a decrease of PLN 0.6 billion in comparison with 2016 but still the secondbest result in the history of media research.

The above result was the consequence of the following in particular:

- qualification by the Polish football team for the FIFA World Cup 2018 in Russia,

- successes of Kamil Stoch and the Polish national team in ski jumping,

- organization of the European Men's Volleyball Championships 2017 in Poland,

- Tour de Pologne 2017.

Table 2. TOP 20 disciplines due to the generated media value for sponsors in 2017 (in relation to the results obtained in 2016 and 2015)

\begin{tabular}{clccc} 
No. & \multicolumn{1}{c}{ DISCIPLINE } & $\begin{array}{c}\text { MEDIA VALUE IN PLN } \\
\text { IN } 2017\end{array}$ & $\begin{array}{c}\text { MEDIA VALUE IN PLN } \\
\text { IN } 2016\end{array}$ & $\begin{array}{c}\text { MEDIA VALUE IN PLN } \\
\text { IN } 2015\end{array}$ \\
\hline 1 & Football & 1700971300 & 1877703152 & 1594013130 \\
2 & Men's volleyball & 825990592 & 932784495 & 376917955 \\
3 & Ski jumping & 823814524 & 252252192 & 280091229 \\
4 & Speedway & 193098997 & 139541398 & 112820300 \\
5 & Road cycling & 142906206 & 140159712 & 187478545 \\
6 & Women's volleyball & 127157984 & 157130463 & 102097314 \\
7 & Martial arts & 101389768 & 82579230 & 65094220 \\
8 & Boxing & 86300933 & 137451593 & 85736098 \\
9 & Athletics & 64530692 & 71144364 & 67651371 \\
10 & Men's handball & 51309718 & 898537918 & 196676151 \\
11 & Men's basketball & 36776123 & 98674669 & 68120942 \\
12 & Hockey & 24843456 & 47301021 & 33359374 \\
13 & Other & 16935268 & 12050286 & 25588618 \\
14 & World games & 15163824 & 0 & 0 \\
15 & Riding & 14227578 & 9046620 & 15074970 \\
16 & Tennis & 12988496 & 51166232 & 55518350 \\
17 & Women's handball & 9888025 & 32128118 & 85025352 \\
18 & Track cycling & 8369623 & 951188 & 450621 \\
19 & Biathlon & 8244088 & 2669229 & 365506 \\
20 & Cross country skiing & 8068592 & 7625979 & 23067781 \\
\hline Source: Own elaboration based on own data of Pentagon Research 2018 & & \\
\hline
\end{tabular}


Television broadcasting groups and sponsors in 2017

- Cyfrowy POLSAT Group took the first place another year in a row regarding the media value of the sports sponsors among the TV groups.

- The largest growth in comparison to the previous period was recorded by EUROSPORT Group (+79\%).

- The ranking of sponsors who had the highest result in the media aspect on the Polish market in 2017 starts with LOTOS Group, PKN Orlen and PLUS (Polkomtel).

- The high results of the Polish football team's sponsors, such as NIKE, STS, Ustronianka and Cinckciarz.pl are also noteworthy.

- It should be added that the large share in the results below was given to OSHEE, a Polish company with global presence which is an official partner of PZPN (Polish Football Association) and the EKSTRAKLASA football league.

- Disciplines which had the highest exposure value of sponsors' brands in 2017 include football, men's volleyball, martial arts (STS, Blachy Pruszyński) and speedway (sponsoring brands: PGE Ekstraliga and Warsaw FIM Speedway Grand Prix of Poland).
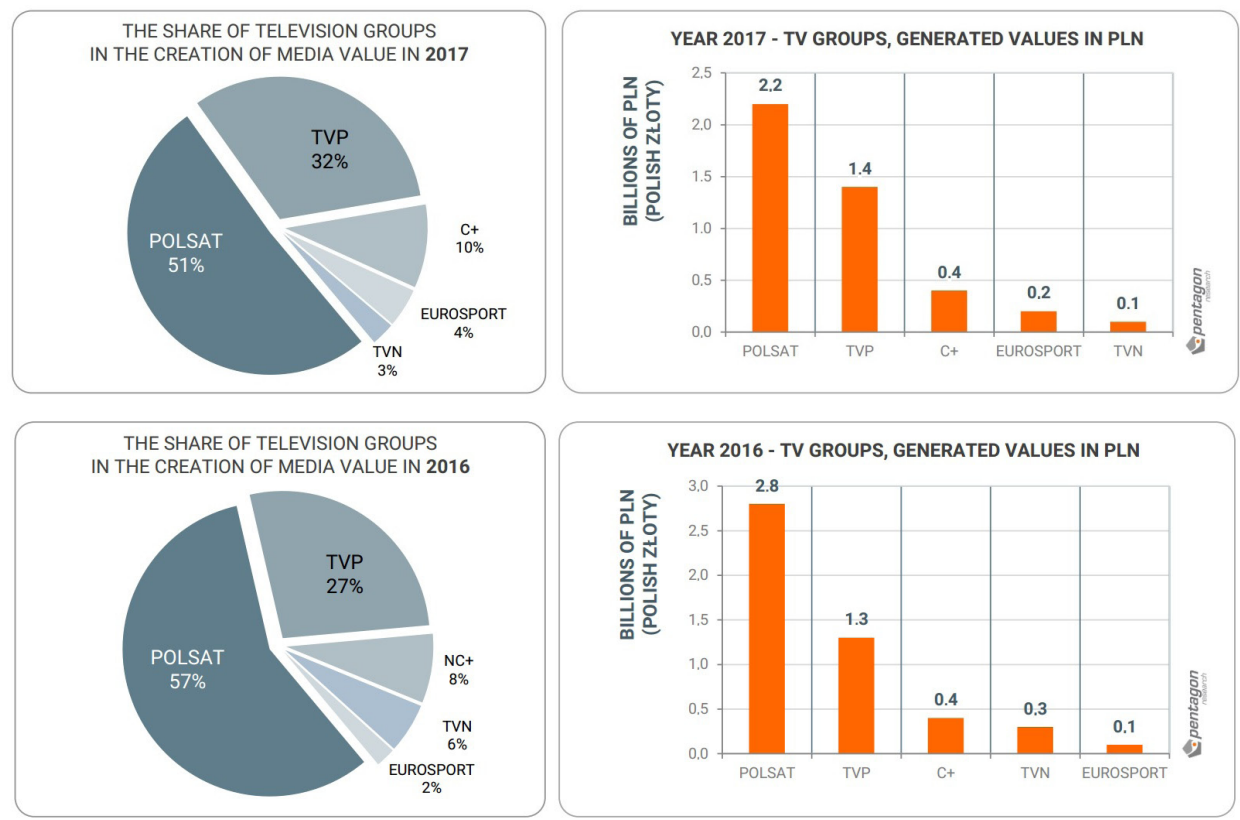

Fig. 4. Share of television groups in the creation of media value for sports sponsors (comparison in the years 2017 and 2016)

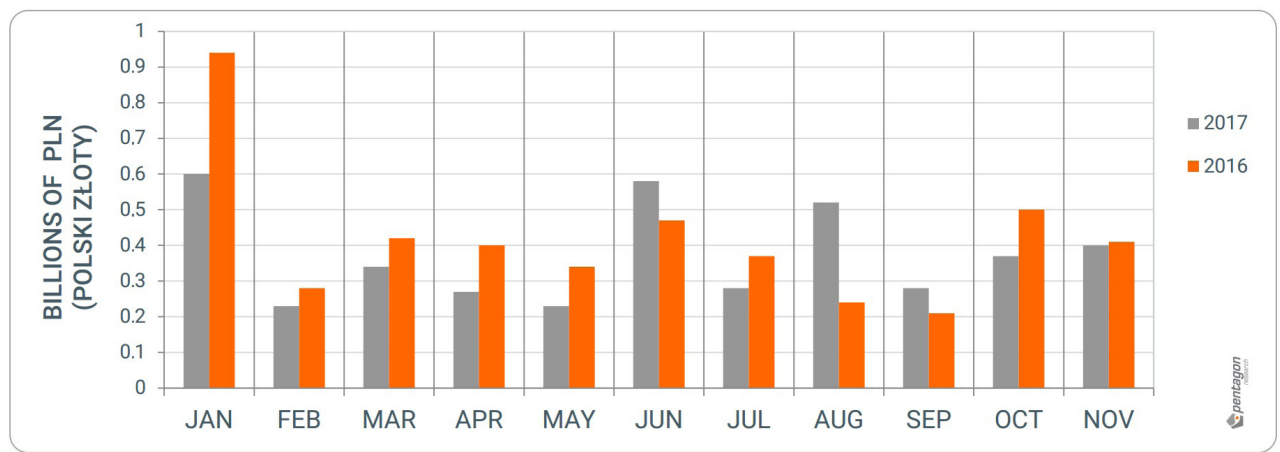

Fig. 5. Value of exposure of sponsors in each month (comparison in 2017 and 2016)

Source: Own elaboration based on own data of Pentagon Research 2018. 
Table 3. Number of noted sponsor brands in the years 2012-2017

\begin{tabular}{cc} 
YEAR & NUMBER OF NOTED SPONSOR BRANDS \\
\hline 2012 & 3629 \\
2013 & 5094 \\
2014 & 6162 \\
2015 & 6612 \\
2016 & 6902 \\
2017 & 6991 \\
\hline
\end{tabular}

Source: Own elaboration based on data from Pentagon Research 2018.

Main conclusions on Table 3:

- The number of sponsors present in Polish sport increases every year.

- From 2012 to 2017 the number of sponsors nearly doubled.

- The years 2015, 2016 and 2017 widely analysed in this article show that the number of sponsors stabilized and is slightly less than 7,000 brands.

- The promotion of brands from year to year is more and more effective.

- For example, the Polish Football Association (PZPN) uses almost every free place to present its sponsors, partners and initiatives.

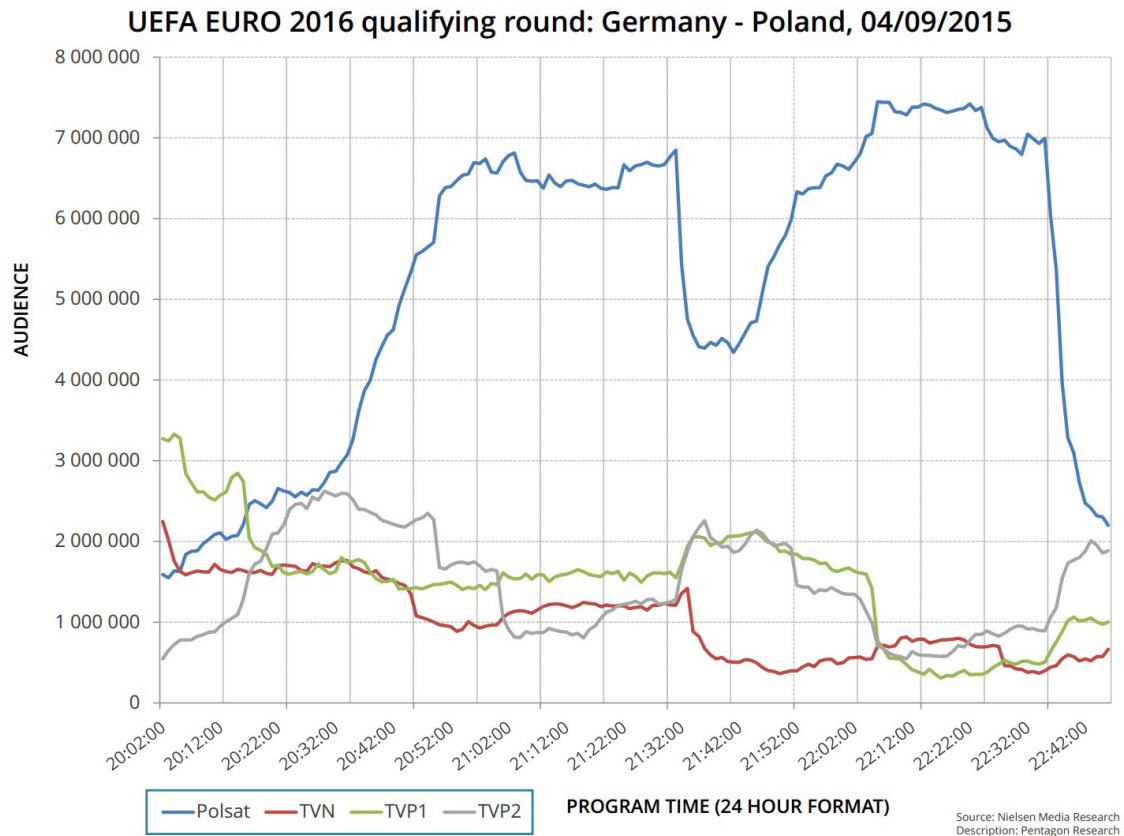

Fig. 6. Indicator curve of minute viewership (audience) of four major Polish TV channels during a qualifying round match of UEFA EURO 2016 Germany-Poland

Source: Own elaboration based on data from Nielson Media Research 2015.

In the above chart, the vertical axis presents the TV audience in viewers, i.e. for each minute of the match broadcast. The horizontal axis, on the other hand, states the passage of time, i.e. the specific hour and minute of the TV broadcast. In general, the chart shows the number of viewers in every minute for the four TV channels in Poland in the presented time interval.

The chart clearly indicates that the viewership of Polsat, a channel broadcasting the Germany-Poland match, started to grow just after 20:30 (the match started at 20:45). The high value of the audience stabilizes around 20:55, or about 10 minutes after the start of the match. Such a delay results from the fact that 
that some people are late and treat the break as an opportunity to go to the toilet, a store or for example to prepare dinner at home, watch another program or forget to switch over to the channel with the match.

At the end of the first half, a very large drop in viewership in a few minutes can be observed. This is a proof of the thesis that viewers dislike advertisements and during the break switch over to other TV channels, and in this case TVP1 and TVP2 gained the most. The switching channels phenomenon, so-called 'channel hopping' even has its name: zapping. The marketing message of sponsors present at this meeting reached the maximum number of viewers, while the marketing message of advertisers presenting themselves around the sport reached a much smaller group of recipients. The sponsors of the broadcast, whose advertisements are presented directly before the sporting event going on air, or immediately after its end, could be presented well indirectly. The chart also shows a clear increase in viewership for the second half of the match. The Poles eventually lost to Germany, who in the 82nd minute sealed a 3-1 victory. The chart clearly shows that after this goal some spectators stopped watching the game, turning off the TV or switching over to another channel.

Equally interesting are the viewership results of the key elimination match of Poland and Ireland on 11 November 2015. The second half of the match is characterized by a viewing pattern very similar to the first half: the only major difference is an additional increase in the number of viewers around 22:12 and at the end of the game. People were more likely to watch the match between Poland and Ireland than other programs; because the real victory of Poles promoted Poland to the UEFA EURO 2016 tournament, it attracted the viewers who wanted to see the promotion to a big football tournament by their national team. The joy from the victory and the immediately following advertisements as a result of which, within a few minutes, Polsat lost over 7 million viewers demonstrate the power of sport and its advantage in terms of building the marketing value over conventional advertising activities. The full result of the viewership rating for this meeting is presented below.

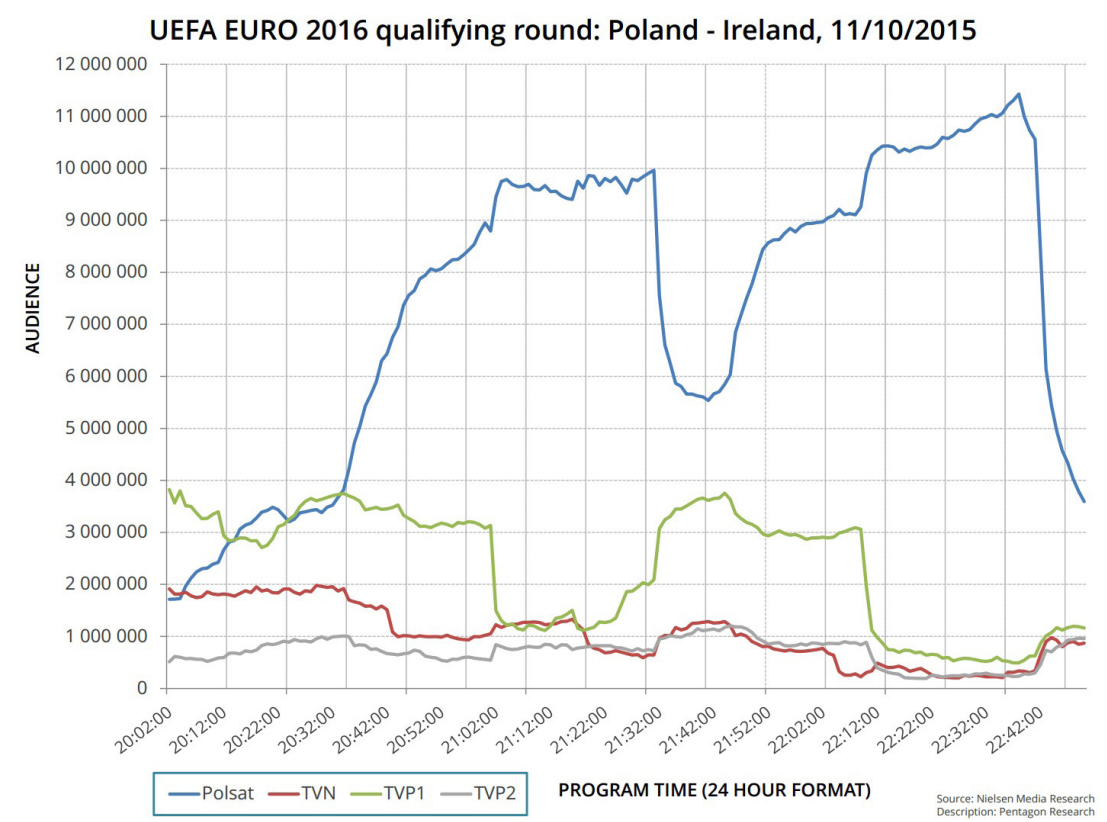

Fig. 7. Indicator curve of minute viewership of four major Polish TV channels during a qualifying round match of UEFA EURO 2016 Poland-Ireland 


\section{DISCUSSION}

The technological progress which we witness nowadays has redefined the role of television in everyday life [17]. It is no longer the most important oracle in homes, as its role has largely been taken over by the Internet for nearly a dozen years, and for at least ten years by the social media. Over the past few years, the expectations of TV audience have undergone tremendous changes. From many examples of market research (including the Connected Life report conducted annually by the TNS research company), it is possible to learn that at present, nearly half of the audience watching TV in the evening at the same time are also looking at a device connected to the Internet (like a tablet or a mobile phone).

However, television is still the surest, most stable medium in the context of events that happen "live". Sports broadcasts on the Internet are often characterized by poor quality or are presented with a long delay, signal fading or other factors hindering reception, even in the case of official, legal media broadcasters.

The many years of experience of television producers and the resulting advantage over the Internet mean that sports games are still broadcast on television almost in terms of the entire media market and television is the least risky, and therefore also the most frequent choice made by the viewer.

Mainly for this reason, in the context of rationalization of sports sponsorship, it is worth using the research methods that thoroughly analyse individual TV channels, as well as encourage scientists and practitioners to work on the refinement of research methods. The power of sports sponsorship results from changes in the competitive advertising market. In view of an increasingly intensified phenomenon of avoiding watching advertisements (e.g. using Internet software, watching VODs (Video-On-Demand) formats) brands are looking for alternative forms of promotion. One of them is, undoubtedly, sports sponsorship.

The universal form of sport in the context of its showing will result in the fact that, when the Internet is ready to take over the role of television technologically and commercially to be the leader in broadcasting sport events, the research methods used will continue to be valid, and in specific cases may require minor modifications. The evolution of the media market continually forces sponsors to rationalise their actions. Even the shortest inactivity can cause the brand's presentation to be carried out in a way that is outdated and unattractive to the viewer of sporting events. The conducted research has confirmed the dominance of football over other disciplines regarding popularity and attractiveness of the television offer, thus generating the highest total media value by this discipline. Disciplines such as handball, volleyball or ski jumping may also reach very high media values for sponsors, but mainly only if spectacular successes are achieved.

The POLSAT Group is the dominant leader on the TV broadcasters market, which generated PLN 2.8 billion in media value in 2016 and PLN 2.2 billion in 2017. It is followed by Telewizja Polska Group which reached PLN 1.3 billion in 2016, and PLN 1.4 billion of media value in 2017. The condition of the sports broadcast rights market in 2018 suggests that TVP will continue to reduce the distance which separates it from the result of the POLSAT Group. The third place among broadcasters with the most frequent display of sponsors (Polish 
sports or Polish sponsors in foreign sports) belongs to NC+, which as a group intended for a smaller, slightly richer audience reaches a much lower value oscillating at PLN 0.4 billion.

\section{CONCLUSIONS}

The most effective method for sports sponsors (and also in a sense, for advertisers using sports) seems to be the creation of promotional and marketing strategies based on the performances of Polish teams at major sporting events with a championship rank in given disciplines or at general sports events, such as the Olympic Games (despite many restrictions on sponsorship at this event). The most valuable discipline for marketing strategies seems to be the one that offers high probability of sustainable, high popularity in the coming months or years. As 2015, 2016 and 2017 years show - there can be many such disciplines. For obvious reasons, this popularity will affect the result of the media value.

Choosing a sport discipline only by its level of mediality may not prove to be a rational choice in the long run. The poor image of individual athletes, or in general of the whole discipline, with its intense mediality will evoke negative emotions and have an obvious impact on consumer decisions.

The average annual media value calculated on the basis of the last five years is record high and amounts to PLN 4.07 billion. The presented growth in the value of the sports sponsoring market over the last years indicates the growing awareness of sports sponsors.

Continuous, growing mediatisation requires a further and more meticulous way to study it. The results of these studies may contribute to clarifying the way of making more rational choices when using sports for marketing, sponsorship, advertising and promotion in the business space.

\section{REFERENCES}

[1] Kopecka-Piech K. Sport - od medialnego zapośredniczenia do mediatyzacji [Sport - from medial mediation to mediatization]. Kultura i Edukacja. 2012;3:243-257. Polish.

[2] Nosal P. Medialne transgresje sportu. In: Kopecka-Piech K, editor. Innowacyjność przemysłów kreatywnych. Media a sport [Creative industry and media innovation]. Wrocław; 2015, 17-37. Polish.

[3] Łasiński G, Pawlukiewicz A. Rozpoznawalność, wizerunek i medialność przedstawicieli polskiego sportu - możliwe implikacje biznesowe [Recognition, image and media of representatives of Polish sport - possible business implications]. Marketing i Zarządzanie. 2018;1(51):235-245. Polish. https:// doi.org/10.18276/miz.2018.51-23

[4] Thompson S. The relationship between sponsorship \& sporting events; The case of McDonald's sponsoring the Olympics. London: London Metropolitan University; 2011.

[5] Mierzwiński J. Sponsoring w usługach sportu jako czynnik rozwoju i promocji [Sponsorship in sports services as a factor of development and promotion]. Prace Naukowe Uniwersytetu Ekonomicznego we Wrocławiu. 2014;355:110-116. Polish. https://doi.org/10.15611/pn.2014.355.10

[6] Łasiński G, Pawlukiewicz A. Wartość mediowa a rozpoznawalność sponsorów sportowych [The value of media and the recognition of sports sponsors]. In: Kopecka-Piech K, editor. Innowacyjność przemysłów kreatywnych. Media a sport [Creative industry and media innovation]. Wrocław; 2015, 109-135. Polish.

[7] Prajecus JW. Seven psychological mechanism through which sponsorship can influence consumers. In: Kahle LR, Riley C, eds. Sports marketing and the psychology of marketing communication. London: Lawrence Erlbaum Associates; 2004, 175-189.

[8] Garland R, Charbonneau J, Macpherson T. Measuring sport sponsorship effectiveness: Links to existing behaviour. Innovative Marketing. 2008;4(1):46-51.

[9] Ungerman-Sears J. Corporate sponsorship vs. traditional advertising in sports: An empirical comparison. Master Thesis. Montreal: Concordia University; 2015, 4-6.

[10] Starcom. Raport roczny (2017) rynku reklamowego w Polsce [Annual report (2017) of the advertising market in Poland] [Available at https://www.wirtualnemedia.pl/artykul/wydatki-reklamowe-w-polscew-2017-roku-wyniosly-8-8-mld-zl-79-proc-trafilo-do-telewizji-i-internetu-w-iv-kwartale-5-5-procwzrostu-raport] [Accessed on 3rd November, 2018]. Polish. 
Baltic Journal of Health and Physical Activity 2019; Supplement (1): 7-19

Journal of Gdansk University of Physical Education and Sport

e-ISSN 2080-9999

[11] Frankfort-Nachmias C, Nachmias D. Metody badawcze w naukach społecznych [Research methods in social sciences]. Zysk i S-ka. Poznań; 2001. Polish.

[12] CPT Cost Per Thousand [Available at https://dobrebadania.pl/cpt-ang-cost-per-thousand/] [Accessed on 7th November, 2018].

[13] AGB Nielsen Media Research Dictionary/TAM GLOSSARY [Available at http://www.nielsentam.tv/ glossary/glossaryQ.asp?type=alpha\&jump=none] [Accessed on 2 November, 2018]. 180-183, 194-198.

[14] Jak mierzy się oglądalność w Polsce [How to measure the viewership in Poland] [Available at: https:// www.wirtualnemedia.pl/artykul/jak-mierzy-sie-ogladalnosc-telewizji-w-polsce] [Accessed on 7th November, 2018]. Polish.

[15] Estibals A. A statistical analysis of television audience measurement systems and their implications. The London School of Economics and Political Science. Thesis for Doctor of Philosophy. 2000; 65-68.

[16] Mytton G. Handbook on radio and television audience research. Paris: UNICEF and UNESCO; 1999, 173.

[17] Jaworska A. Kto ogląda dziś telewizję? Zarządzanie widownią telewizyjną w obliczu postępującej innowacji/Who watches TV today? Managing the television audience in the face of ongoing innovation. Logistyka. 2015;1496:1231-5478. https://www.czasopismologistyka.pl/artykuly-naukowe/ download/329-artykuly-na-plycie-cd-2/7427-artykul 